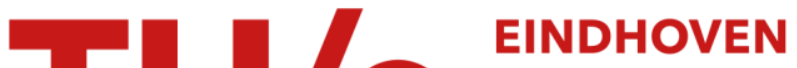 UNIVERSITY OF TECHNOLOGY
}

\section{An improved technology for eliminating polarization dispersion in integrated phasar demultipliers}

Citation for published version (APA):

Vreeburg, C. G. M., Herben, C. G. P., Leijtens, X. J. M., Smit, M. K., Groen, F. H., Tol, van der, J. J. G. M., \& Demeester, P. (1997). An improved technology for eliminating polarization dispersion in integrated phasar demultipliers. In IOOC-ECOC 97 : 11th International Conference on Integrated Optics and Optical Fibre Communications ; 23rd European Conference on Optical Communications (pp. 83-86). (IEE Conference publication; Vol. 448). Institute of Electrical Engineers.

Document status and date:

Published: 01/01/1997

\section{Document Version:}

Publisher's PDF, also known as Version of Record (includes final page, issue and volume numbers)

\section{Please check the document version of this publication:}

- A submitted manuscript is the version of the article upon submission and before peer-review. There can be important differences between the submitted version and the official published version of record. People interested in the research are advised to contact the author for the final version of the publication, or visit the $\mathrm{DOI}$ to the publisher's website.

- The final author version and the galley proof are versions of the publication after peer review.

- The final published version features the final layout of the paper including the volume, issue and page numbers.

Link to publication

\section{General rights}

Copyright and moral rights for the publications made accessible in the public portal are retained by the authors and/or other copyright owners and it is a condition of accessing publications that users recognise and abide by the legal requirements associated with these rights.

- Users may download and print one copy of any publication from the public portal for the purpose of private study or research.

- You may not further distribute the material or use it for any profit-making activity or commercial gain

- You may freely distribute the URL identifying the publication in the public portal.

If the publication is distributed under the terms of Article 25fa of the Dutch Copyright Act, indicated by the "Taverne" license above, please follow below link for the End User Agreement:

www.tue.nl/taverne

Take down policy

If you believe that this document breaches copyright please contact us at:

openaccess@tue.nl

providing details and we will investigate your claim. 


\title{
AN IMPROVED TECHNOLOGY FOR ELIMINATING POLARIZATION DISPERSION IN INTEGRATED PHASAR DEMULTIPLEXERS
}

\author{
J.J.G.M. van der $\mathrm{Tol}^{+}$and P. Demeester ${ }^{*}$ \\ Faculty of Electrical Engineering, \\ Delft University of Technology, P.O. Box 5031, \\ NL-2600 GA, Delft, The Netherlands \\ vreeburg@et.tudelft.nl \\ *Research Group for Optics, \\ Department of Applied Physics, \\ Delft University of Technology, The Netherlands
}

C.G.M. Vreeburg, C.G.P. Herben, X.J.M. Leijtens, M.K. Smit, F.H. Groen*,

${ }^{+}$KPN-Research, Royal PTT Netherlands N.V., Leidschendam, The Netherlands

\#University of Gent-IMEC,

Department of Information Technology, Belgium

\section{Abstract}

An improved technology for realizing high quality PHASARs is reported compatible with the integration of electro-optical switches. This technology is demonstrated in a 16-channel polarization independent low loss $(<1.7 \mathrm{~dB})$ PHASAR.

\section{Introduction}

Recently we reported a 4-channel reconfigurable add-drop multiplexer (ADM) [1], consisting of a single PHASAR demultiplexer integrated with four Mach-Zehnder interferometer switches. This component, which was the first ADM realized on InP, combined a compact device size $\left(3 \times 6 \mathrm{~mm}^{2}\right)$ with good loss and crosstalk figures. However, the ADM was not polarization-independent. In this paper we report an improved technology, compatible with the fabrication of the ADM, to realize a polarization dispersion compensated PHASAR demultiplexer. Earlier we reported a polarization dispersion compensated PHASAR [4] based on the approach proposed by Takahashi [2] and Zirngibl [3]. For the specific waveguide structure of the ADM, required for our integration scheme, this approach introduced low loss for TE-polarization but an additional $2 \mathrm{~dB}$ loss for TM-polarization [4]. In this device the whole InP cladding layer was removed in the polarization dispersion compensation region. Our improved approach combines a local reduction in waveguide width with removal of part of the InP top layer. This gives lower loss and reduced sensitivity to the InP top layer thickness. We demonstrate this technology for a 16-channel PHASAR on InP. On-chip losses are as low as $1.2 \mathrm{~dB}$ and $1.7 \mathrm{~dB}$ for TE- and TM-polarization, crosstalk is better than $-20 \mathrm{~dB}$ and residual polarization dispersion is $<0.2 \mathrm{~nm}$.

\section{Design}

In a polarisation dispersion compensated PHASAR, part of the original array waveguide structure is replaced by a second waveguide structure with a different polarization dispersion. By properly choosing the incremental path 
length difference $\delta l$ between two adjacent compensating waveguides, the polarization dispersion in this section can compensate the dispersion in the original waveguide structure [2], [3]. The incremental length $\delta l$ of the compensating waveguide is given by:

$$
\delta l=\frac{\Delta \lambda_{N}}{\Delta \lambda_{n}-\Delta \lambda_{N}} \cdot \Delta L,
$$

in which $\Delta \lambda_{n}$ and $\Delta \lambda_{N}$ are the polarization dispersion in the normal and compensating waveguides and $\Delta L$ is the incremental arm length difference in the PHASAR. Due to the linear increase in arm length the compensating waveguides form a triangular shaped region, see Fig. 1.

The length of the triangular section and thus the dimension of the PHASAR can be minimized by using two waveguide structures with a large difference in polarization dispersion. The starting point is the original waveguide structure required for our integration scheme, see Fig. 1. A large difference in polarization dispersion can be obtained by removing the whole InP top layer. However, this results in an increased loss for the PHASAR, especially for TM-polarization [4]. Our improved technology avoids this loss by combining removal of part of the InP top layer with a reduction in waveguide width.

The polarization dispersion in the compensating waveguide is increased by reducing the waveguide width from $3.0 \mu \mathrm{m}$ to $1.5 \mu \mathrm{m}$ with a linear taper of $50 \mu \mathrm{m}$ length. The polarization dispersion of the compensating waveguides is further increased by removing part of the InP top layer at the price of coupling loss at the transition between the two waveguide sections. The polarization dispersion and this coupling loss as a function of the InP top layer thickness in the compensating waveguides are shown in Fig. 2. Both the polarization dispersion and the coupling loss increases for decreasing InP top layer thickness.

As a compromise between low coupling loss and sufficient polarization dispersion we have chosen a $0.2 \mu \mathrm{m}$ thick InP top layer in the compensating waveguides. Measured polarization dispersion of the normal waveguide structure $(3.0 \mu \mathrm{m}$ wide and $1.2 \mu \mathrm{m}$ thick InP top layer) and of the triangular section $(1.5 \mu \mathrm{m}$ wide and $0.2 \mu \mathrm{m}$ thick InP top layer) were $3.1 \mathrm{~nm}$ and $5.7 \mathrm{~nm}$, respectively. For a 16-channel PHASAR with $3.2 \mathrm{~nm}$ channel spacing we have chosen a free spectral range of $51.2 \mathrm{~nm}(\Delta L=12.07 \mu \mathrm{m})$, which results in an incremental length of $\delta l=15 \mu \mathrm{m}$ for the compensating waveguides. Total device size of the PHASAR, excluding access waveguides, is $3.3 \times 1.3 \mathrm{~mm}^{2}$.

An important loss contribution in a PHASAR is the transition between the free propagation region and the array of waveguides. Loss dependence on the gap between the $3 \mu \mathrm{m}$ wide array waveguides is depicted in Fig. 3. This loss includes coupling loss between the free propagation region and the array waveguides, losses caused by offsets between straight and curved waveguides and radiation loss in the curved waveguides. Offset loss and radiation loss can be very low $(<0.2 \mathrm{~dB})$. Coupling loss between the free propagation region and the array guides is calculated by diffraction of the input field with a Rayleigh-Sommerfeld approximation, overlapping of the diffracted field with the supermodi in the array-waveguides and finally overlapping of the supermodi with the modi in the separate array waveguides [6]. Due to the restricted lithographic resolution we have chosen a gap of $0.6 \mu \mathrm{m}$, which results in a simulated excess loss of $1 \mathrm{~dB}$.

\section{Fabrication}

The PHASAR was fabricated in a MOVPE grown layer stack as shown in Fig. 1. A $100 \mathrm{~nm}$ thick PECVD-SiN layer served as an etching mask for the waveguides. The pattern was defined using contact illumination with positive photoresist and transferred in the SiN-layer by $\mathrm{CHF}_{3}$ reactive ion etching. The waveguides were etched employing an optimized $\mathrm{CH}_{4} / \mathrm{H}_{2}$ etching and $\mathrm{O}_{2}$-descumming process as described by [5]. The top layer of the waveguides in the compensating waveguides was etched through an opening in photoresist. First the SiN mask 
was removed by $\mathrm{CHF}_{3}$ reactive ion etching and then the InP was wet chemically etched with a selective etch $\left(\mathrm{HCl}: \mathrm{H}_{3} \mathrm{PO}_{4}=1: 4\right)$ up to the $\mathrm{Q}(1.3)$ etch stop layer. After removal of photoresist the wafer processing was finished.

\section{Experimental Results}

The PHASAR was measured using an EDFA as a broadband light source and a polarizer to select the polarization. Light was coupled in the anti-reflection coated chip using microscope objectives and coupled out of the waveguides by a single mode tapered fiber. The light was analyzed using an optical spectrum analyzer. Propagation loss of $3.0 \mu \mathrm{m}$ wide straight reference waveguides was $1.5 \mathrm{~dB} / \mathrm{cm}$ for both polarizations. Fig. 3 shows the response of all sixteen channels of the PHASAR for both polarization. Average channel loss for TE- and TMpolarization was $1.3 \mathrm{~dB}$ and $1.7 \mathrm{~dB}$, respectively. Channel uniformity is better than $0.5 \mathrm{~dB}$ and measured excess losses are slightly higher than simulated losses. Polarization dispersion of all channels was smaller than $0.2 \mathrm{~nm}$, channel crosstalk was better than $-20 \mathrm{~dB}$. Channel spacing of $3.3 \mathrm{~nm}$ is slightly larger than the design value of $3.2 \mathrm{~nm}(400 \mathrm{GHz})$.

\section{Conclusions and Discussions}

A 16-channel polarization independent PHASAR demultiplexer with good performance has been realized. Layer structure and fabrication process are compatible with the fabrication of wavelength routing devices such as ADM or OXC, reported earlier by us [1]. Excess loss is lower than $1.7 \mathrm{~dB}$ for both polarizations and the polarization dependence is smaller than $0.2 \mathrm{~nm}$. This type of PHASAR, in combination with polarization independent MachZehnder Interferometer switches [7] allows for the realization of polarization independent ADMs.

\section{Acknowledgments}

This work was partly supported by the ACTS AC-065 project BLISS. Anja Suurling and Adrie Looyen are acknowlegded for EBPG mask fabrication and AR-coatings, respectively.

\section{References}

1. C.G.M. Vreeburg et al., "First InP-based reconfigurable integrated add-drop multiplexer," IEEE Photon. Technol. Lett, vol. 9, no. 2, pp. 191-193, 1997

2. H. Takahashi et al., "Polarization-insensitive arrayed-waveguide grating multiplexer with birefringence compensated film," IEEE Photon. Technol. Lett, vol. 5, no. 6, pp. 707-709, 1993

3. M. Zirngibl et al., "Polarisation compensated waveguide grating router on InP," Electon. Lett. vol 31, no. 19, pp. $1662-1664$

4. C.A.M. Steenbergen et al., "Compact low loss $8 \times 10 \mathrm{GHz}$ polarisation independent WDM receiver," in Proc. 22nd Eur. Conf. on Opt. Comm. (ECOC '96), pp. 1.129-1.132, Oslo, Norway, 1996

5. Y. Oei et al.,"Novel RIE-process for high quality InP-based waveguide structures," Proc. 7th Eur. Conf. on Int. Opt. (ECIO'95), Delft, The Netherlands, pp. 205-208, 1995

6. X.J.M. Leijtens et al., "S-matrix oriented CAD-tool for simulating complex integrated optical circuits," IEEE J. on Selec. Topics in Quant. Electron., vol. 2, no. 2, pp. 257-262, 1996

7. T. Uitterdijk et al., "Dilated, polarisation insensitive InP-based space switch," Proc. 8th Eur. Conf. on Int. Opt. (ECIO'97), Stockholm, Sweden, 1997 


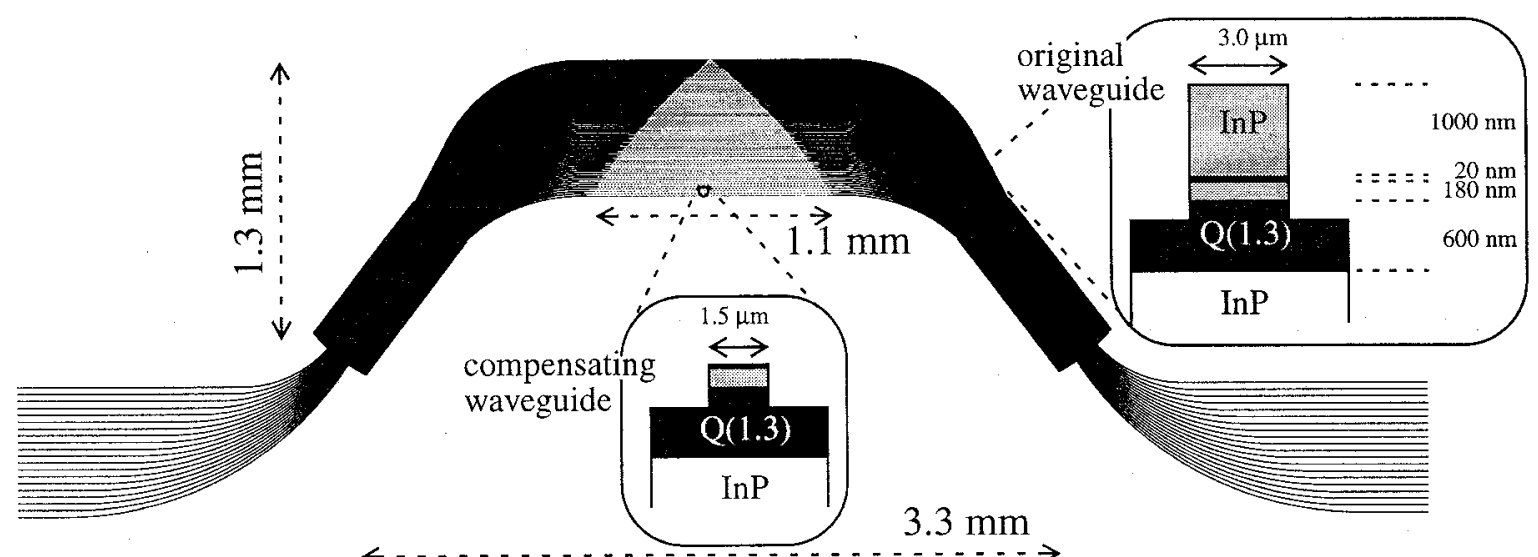

Fig. 1. Layout of the PHASAR demultiplexer and dimensions of the two waveguide structures in the array arms of the PHASAR.

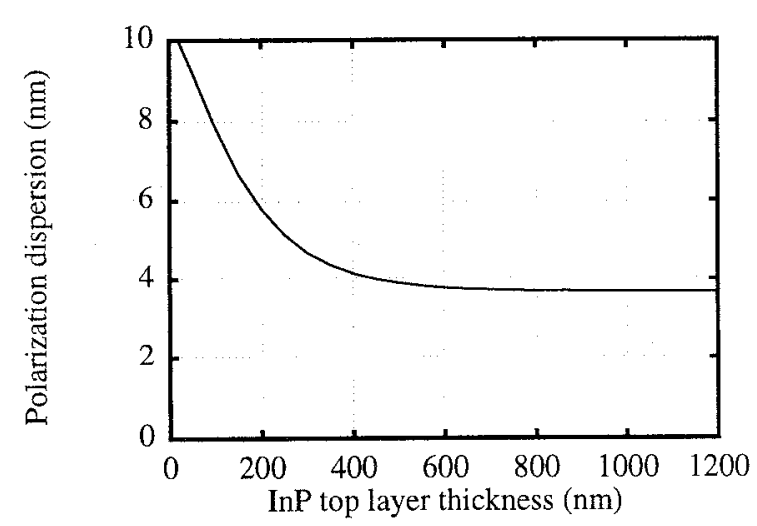

(a)

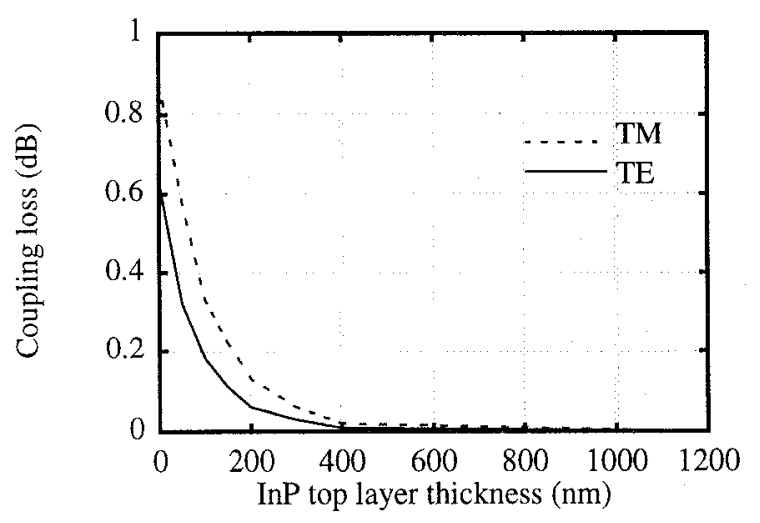

(b)

Fig. 2. (a) Polarization dispersion and (b) coupling loss between the two waveguide structures as a function of the InP toplayer thickness of the compensating waveguides (width $=1.5 \mu \mathrm{m}$ ).

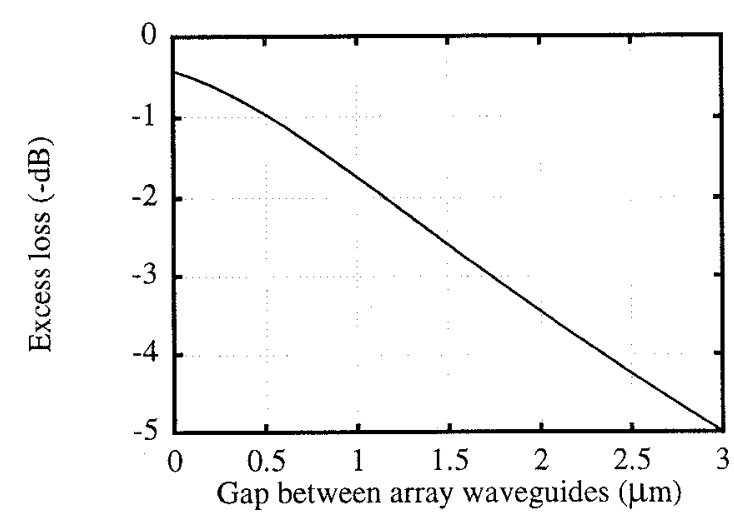

(a)

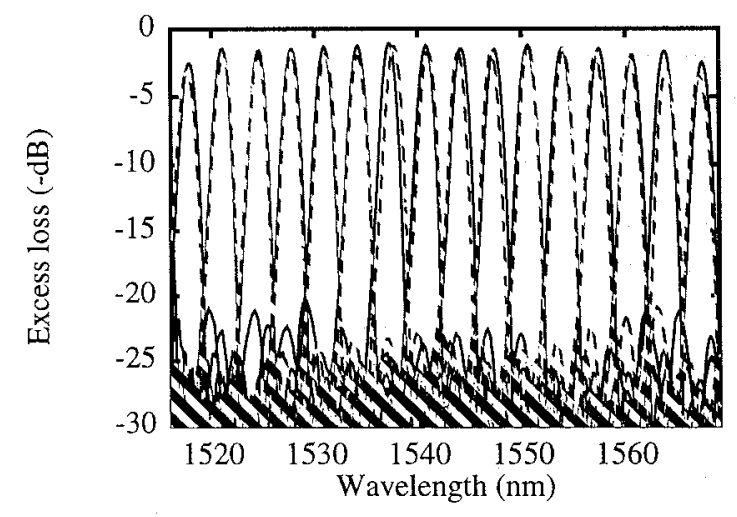

(b)

Fig. 3. (a) Simulated loss for the central channel of a PHASAR as a function of the gap between the array waveguides. (b) Spectral response of the PHASAR for all sixteen channels; TE- (solid) and TM-polarization (dashed). 